Among so many articles, all of which are so well written it would seem invidious and perhaps unfair to attempt to make comparisons, but the reviewer cannot refrain from special mention of the following. Sir Henry Cohen's observations are conspicuous for the comprehensiveness of view and clarity of expression which characterize all his lectures; his contribution on General Medicine is, in many ways, a key to the book as a whole. Sir Arthur Porritt's refreshing chapter on General Surgery is undoubtedly one of the best for its facts and its philosophy. Dr. Dobbs's remarks on Paediatrics are especially delightful for their insight and commonsense appreciation of the qualities essential for a good children's doctor. Dr. Barber's advice on General Practice should be read by everyone, whatever his or her special leanings; he gives an extremely fair, broad description, if a little over optimistic, perhaps, of the present day position.

In addition to the sections on the varieties of the clinical curriculum, there are excellent chapters on the pre-clinical subjects and their possibilities as a whole-time career. There is also a fund of information on Legal Medicine, Social and Preventive Medicine, Medicine in the Services, and several appendices giving necessary details of the regulations for postgraduate diplomas, scales of pay in various departments and a useful commentary on the working of the National Health Service.

Here and there are many delightful obiter dicta which add to the enjoyment which the intelligent reader will derive from a perusal of this really good and much needed book. Not only is it a guide to the student on the threshold of a medical career, it should be in the possession of every headmaster of a large school who has any true sense of his vocation.

We have only one minor criticism. In our view future editions of this work will gain much by the addition of a good index.

Maurice Davidson.

\section{THE SCIENTIFIC PAPER}

By S. F. Trelease. 2nd Edition. Pp. xii $+\mathrm{I} 6_{3}$, with 8 illustrations. London: Baillière, Tindal \& Cox. I95I. 20s.

It is stated in the preface that this book is intended to meet the practical needs of students and research workers preparing scientific papers. The author has endeavoured, in just over 150 small pages, to cover every aspect of the subject. He starts by giving advice on the choice of a research problem and includes such diverse subjects as the use of the library in scientific work, statistical methods, syntax and the writing of English, botanical and zoological nomenclature, abbreviations of the names of scientific periodicals, proof reading and, perhaps most remarkable of all, he includes a section on photography which even gives advice about the choice of different makes and types of lenses. All these articles are of necessity extremely short and in consequence the majority are of limited value. For example, the section on statistical methods is practically confined to a very brief consideration of Fisher's test. The book also is loaded with self-evident statements. It would, for instance, be difficult to imagine a group of readers who would find the following observation of any real help :

' In choosing a research problem, special knowledge of a particular field of science is indispensable' (page I).

However, in spite of its many drawbacks, the book does contain quite a lot of information which should be of value to a student writing his first scientific paper.

\section{A TEXTBOOK ON THE NURSING DISEASES OF SICK CHILDREN NURSES}

Edited by Alan MoncriefF, M.D., F.R.C.P. Edition. Pp. xiv +770 with I6r illustrations. London: H. K. Lewis and Co. Ltd. I952 N 37s. $6 \mathrm{~d}$.

A new edition of a well proven textbook is always welcome. This is a book essentially for those nursing sick children but the amount of ground covered briefly but adequately makes it of $\frac{Q}{D}$ value to student and practitioner.

The contents are well set out, illustrated and make $\overrightarrow{\vec{O}}$ easy reading. There have been new chapters added $\frac{}{3}$ on bacteriology, plastic and thoracic surgery. Many other chapters have been completely revised and brought up to date, notably the sections on anaesthetics and drugs. Orthopaedics have been treated $\frac{3}{3}$ very fully and the drawings are most helpful. Dietetics and infant feeding are easily understood 3 and the recipes are written with an eye to present. day restrictions. This makes the nurse's task of $\mathcal{O}$ instructing parents on feeding problems much simpler.

This book is not intended to be an exhaustive reference volume. No mention however has been made of the management of balances carried out to aid diagnosis and judge progress in such cases as $\mathcal{N}$ coeliac disease and nephro-calcinosis. The latter $N$ together with other metabolic disturbances have $N$ been completely omitted from the text. The section on congenital disease of the heart would have benefited by more detail, and fibro-cystic disease of theo pancreas has been dealt with in three lines! 
These are minor points as the editor's task of producing a book to cover not only the nursing but also the diseases of children and yet to keep the cost within the limits of a nurse's pocket, cannot have been easy.

All contributors are members of the staff of the Hospital for Sick Children, Great Ormond Street, and consequently the teaching is essentially as practised at that hospital, which for basic training in nursing might be equalled elsewhere but surely could not be bettered.

\section{DEFICIENCY DISEASES IN JAPANESE PRISON CAMPS}

\section{(M.R.C. Special Report Series No. 274)}

By D. A. Sмith, O.B.E., M.A., M.D., D.T.M. \& H., and M. F. A. WoodruFF, M.D., M.S., F.R.C.S. . Pp. viii +209 , with 5 illustrations. London: H.M.S.O., 195I. 6s. 6d.

During their captivity, Australian and British medical and lay personnel studied the effects of prolonged and severe under-nutrition upon themselves and other prisoners of war. This report of their work is excellent. The clear and concise style of the authors excites attention. The results of their work command interest and supply a considerable volume of information on many aspects of the effects of malnutrition in the Far East.

\section{CIBA FOUNDATION:}

\section{COLLOQUIA ON ENDOCRINOLOGY}

\section{Vol. I-Steroid Hormones and Tumour Growth Steroid Hormones and Enzymes}

Edited by the General Editor for the Ciba Foundation, G. E. W. Wolstenholme, O.B.E., M.A., M.B., B.CH. Pp. $x x+315$ with 48 illustrations. London: J. \& A. Churchill Ltd. I952. 30 S.

The Ciba Foundation was founded in 1949 as an international centre where medical and chemical research workers are encouraged to meet informally to exchange ideas and information.

Volume I of the 'Colloquia on Endocrinology' contains the proceedings of two of these informal meetings. The first one covers the induction of malignant growth by steroids, with special reference to the mammary gland. It touches upon the clinical use of steriods in cancer therapy and deals also with the chemical and metabolic effects of ACTH and cortisone in neoplastic disease. The second meeting deals with steroid hormones and enzymes, mainly B-blycuronidase.

The subject matter of the papers and discussion, as well as the full references, should be of interest to the laboratory research worker in this field rather than to the clinician.

\section{Proceedings of the}

\section{THIRD INTERNATIONAL CONGRESS}

\section{of the INTERNATIONAL SOCIETY of} HAEMATOLOGY

Edited by a committee headed by C. V. Moore. Pp. xvii +503 , illustrated. London: William Heinemann Ltd. 1951. 70s.

The 203 papers read at the Cambridge Congress of the International Society of Haematology in August I 950 are collected in this handsome volume which will be welcomed by everybody who is interested in the various aspects of disorders of the blood, immuno-haematology and coagulation. It reflects fairly the renaissance of haematology and its progress during the last few years. Unlike in many other field of medicine, we have come a long way since Virchow first described leukaemia in I 845 and Addison in 1868 described pernicious anaemia, which is really no longer pernicious. The isolation and properties of vitamin $B_{12}$ were described in the first paper of the Congress by its discoverer, E. Lester Smith, and more than a dozen other papers deal with macrocytic anaemia. Haemolytic anaemia and hypersplenism are the subject of several others. The second main section is devoted to blood groups, agglutinins, antibodies and their interactions. Unfortunately, J. J. van Loghem's review is not included. He said that research in blood groups today resembled the gold rush of other days. So far eight different systems have been identified and between them they provided 70,000 serological combinations, although some of them were not compatible with life. It seemed that Landsteiner's saying that blood groups are as individual as finger prints was true after all. The third main section deals with leukaemia and related diseases. In spite of many advances in the fields of experimental pathology, histo-chemistry, clinical research and therapeutic approach the cause of leukaemia remains unknown and it is still an incurable disease. Except in acquired haemolytic syndromes occurring in leukaemia or related disorders, ACTH and cortisone was reported by most workers to be most disappointing. The section on coagulation, purpura and related subjects shows that an enormous amount of work has been done and is still done on clotting and clotting factors, but one cannot help wondering whether theory has sometimes been allowed to run wild at the expense of practice. The multiplicity of names for clotting factors is certainly confusing.

The appendices record the scientific exhibits shown at the Congress and the list of officers and constitution of the International Society of Haematology. These are followed by author and subject indices. The book is a credit to the society, the publishers, and particularly to $C$. V. Moore, the editor, and his committee. Almost like the Congress itself, it is bibliography come to life.

E.N. 